\title{
Response to: Olry de Labry Lima A et al., Cost-effectiveness of lenalidomide maintenance in patients with multiple myeloma who have undergone autologous transplant hematopoietic progenitor cells
}

\author{
Sujith Dhanasiri ${ }^{1}$
}

Received: 3 October 2019 / Revised: 14 October 2019 / Accepted: 4 November 2019 / Published online: 21 November 2019

(c) The Author(s) 2019. This article is published with open access

\section{To the Editor:}

Lenalidomide maintenance therapy is recommended for patients with newly diagnosed multiple myeloma (MM) post autologous stem cell transplant (ASCT) by current treatment guidelines such as the ESMO guidelines [1]. Many countries have approved the product for the indication, and offer reimbursement for the treatment, based on a substantial body of evidence indicating that, compared with no maintenance therapy, lenalidomide provides clinically meaningful and significant improvements in progressionfree survival, overall survival, and health-related quality of life (HRQoL) [2-8].

In addition to the safety and efficacy of a product, the cost-effectiveness and budget impact of lenalidomide maintenance therapy are key considerations when making treatment decisions, and it is important that such analyses are performed using robust methodology and based on accurate clinical data and assumptions. We are thus concerned to note two important inaccuracies in the cost-effectiveness analysis recently published in Bone Marrow Transplantation by Antonio Olry de Labry Lima et al. in the article entitled "Cost-effectiveness of lenalidomide maintenance in patients with MM who have undergone autologous transplant of hematopoietic progenitor cells", namely assuming a time horizon of 10 years in the base case, and reporting a total drug cost for lenalidomide maintenance therapy of EUR 535,407.

First, trials of ASCT in MM report an average patient age of $55-59$ years and $64 \%$ of patients included in the IFM trial

Sujith Dhanasiri

sdhanasiri@celgene.com

Celgene International Sarl, Boudry, Switzerland were aged $\leq 59$ years $[2,3,5]$. Thus, the time horizon of 10 years used in the base case for Olry de Labry Lima's analysis to reflect the maximum remaining life of patients is too short to capture the full costs of treatment post ASCT, including the costs of later lines of therapy for patients relapsing post ASCT. Indeed, according to the data presented in Fig. 1 of the paper by Olry de Labry Lima et al., none of the curves show full occupancy for death health state at 10 years, as would be expected after a true lifetime horizon. Furthermore, results for a sensitivity analysis using a 20-year time horizon resulted in substantial reductions to the incremental cost-effectiveness ratio (ICER). Together these results suggest that a 10 -year time horizon does not capture all relevant outcomes for patients post ASCT.

Second, the reported total cost of lenalidomide maintenance therapy appears to assume a total treatment duration of 65 months (based on their stated monthly cost of EUR 8175), whereas trials report a median duration of lenalidomide therapy of 25-35 months [6]. Both assumptions inflate the ICER for lenalidomide maintenance therapy and suggest that this highly effective treatment is not cost-effective.

Various scientific publications have shown that lenalidomide delays disease progression, increases the duration of disease-free periods, and delays progression to later-line regimens involving novel combination therapies without detriment to quality of life [9-11]. These effects can be expected to result in cost savings compared with no maintenance therapy. Finding lenalidomide maintenance therapy to have an ICER of more than EUR 250,000/qualityadjusted life year (QALY) compared with no maintenance therapy, as suggested by Olry de Labry Lima's results, is therefore counterintuitive. In contrast, a cost-effectiveness analysis from the Dutch national health service perspective reported an ICER of approximately EUR 30,000/QALY for lenalidomide maintenance therapy [12]. 
For economic evaluations to be used as part of treatment decision-making, it is important that they provide an accurate evaluation of cost-effectiveness, since concluding a treatment is not cost-effective may have implications for patient access to life-prolonging therapies that improve their HRQoL. We suggest that Olry de Labry Lima's analysis is not an accurate economic evaluation of lenalidomide maintenance therapy, based on the points highlighted above.

\section{Compliance with ethical standards}

Conflict of interest SD is an employee of Celgene International, and has equity interest in the company.

Publisher's note Springer Nature remains neutral with regard to jurisdictional claims in published maps and institutional affiliations.

Open Access This article is licensed under a Creative Commons Attribution 4.0 International License, which permits use, sharing, adaptation, distribution and reproduction in any medium or format, as long as you give appropriate credit to the original author(s) and the source, provide a link to the Creative Commons license, and indicate if changes were made. The images or other third party material in this article are included in the article's Creative Commons license, unless indicated otherwise in a credit line to the material. If material is not included in the article's Creative Commons license and your intended use is not permitted by statutory regulation or exceeds the permitted use, you will need to obtain permission directly from the copyright holder. To view a copy of this license, visit http://creativecommons. org/licenses/by/4.0/

\section{References}

1. Moreau P, San Miguel J, Sonneveld P, Mateos MV, Zamagni E, Avet-Loiseau H, et al. Multiple myeloma: ESMO clinical practice guidelines for diagnosis, treatment and follow-up. Ann Oncol. 2017;28:iv52-iv61.

2. Attal M, Lauwers-Cances V, Marit G, Caillot D, Moreau P, Facon $\mathrm{T}$, et al. Lenalidomide maintenance after stem-cell transplantation for multiple myeloma. N Engl J Med. 2012;366:1782-91.
3. McCarthy PL, Owzar K, Hofmeister CC, Hurd DD, Hassoun H, Richardson PG, et al. Lenalidomide after stem-cell transplantation for multiple myeloma. N Engl J Med. 2012;366:1770-81.

4. Palumbo A, Cavallo F, Gay F, D Raimondo F, Ben Yehuda D, Petrucci MT, et al. Autologous transplantation and maintenance therapy in multiple myeloma. N Engl J Med. 2014;371:895-905.

5. McCarthy PL, Holstein SA, Petrucci MT, Richardson PG, Hulin $\mathrm{C}$, Tosi $\mathrm{P}$, et al. Lenalidomide maintenance after autologous stemcell transplantation in newly diagnosed multiple myeloma: a metaanalysis. J Clin Oncol. 2017;35:3279-89.

6. Jackson GH, Davies FE, Pawlyn C, Cairns DA, Striha A, Collet $\mathrm{C}$, et al. Lenalidomide maintenance versus observation for patients with newly diagnosed multiple myeloma (Myeloma XI): a multicentre, open-label, randomised, phase 3 trial. Lancet Oncol. 2019;20:57-73.

7. Holstein SA, Jung S-H, Richardson PG, Hofmeister CC, Hurd DD, Hassoun $\mathrm{H}$, et al. Updated analysis of CALGB (Alliance) 100104 assessing lenalidomide versus placebo maintenance after single autologous stem-cell transplantation for multiple myeloma: a randomised, double-blind, phase 3 trial. Lancet Haematol. 2017;4:e431-42.

8. McCarthy PL, Richardson P, Suman V, Cooper M, Saunders O, Dhanasiri S, et al. Survival analysis from the CALGB study of lenalidomide maintenance therapy in newly diagnosed multiple myeloma post-autologous stem cell transplantation adjusted for crossover (Alliance 100104). Blood. 2018;132:abstract 4737.

9. Jackson G, Dutton R, Zamagni E, Hughes R, Dhanasiri S. Lenalidomide maintenance therapy post-autologous stem cell transplant: a healthcare cost-impact analysis in Europe. Blood. 2017; 130:abstract 3405.

10. Ashcroft J, Taylor-Stokes G, Dhanasari S, Judge D. Assessing real-world treatment patterns, outcomes and resource use across Europe in newly diagnosed multiple myeloma (NDMM) patients post autologous stem cell transplant. Haematologica. 2017;102: abstract E1463.

11. Tay J, Vij R, Norkin M, Buadi F, Kindwall-Keller TL, Roberts JS, et al. Health related quality of life for multiple myeloma patients according to treatment strategy after autologous stem cell transplant: a cross-sectional study using EORTC, EQ-5D and MY-20 scales. Leuk Lymphoma. 2019;60:1275-82.

12. Uyl-de Groot CA, Ramsden R, Boersman J, Zweegman S, Dhanasiri S. Lenalidomide as maintenance treatment for patients with newly diagnosed multiple myeloma post-autologous stem cell transplantation: a pharmacoeconomic assessment in the Netherlands. Blood. 2018;132:abstract 3555. 